were measured. According to a Clopper-Pearson interval 26-70\% of the patients were underdosed and the exposure to piperacillin was too low. Only in 9 of 20 patients treated with ciprofloxacin $200 \mathrm{mg}$ twice per day the calculated AUIC averaged $\geq 125 \mathrm{~h}$ and the Cmax/ MIC ratio $\geq 10$. Thereby $29-76 \%$ of patients treated with ciprofloxacin were underdosed. With regard to the total body clearance $29 \%$ of piperacillin and $16 \%$ of ciprofloxacin were eliminated by CRRT. Despite the moderate rate of CICRRT the exposure of the patients to piperacillin and ciprofloxacin was revealed to be inadequate.

Conclusions In critically ill patients undergoing CRRT for piperacillin/tazobactam increased doses of $4 / 0.5 \mathrm{~g}$ four times per day and for ciprofloxacin doses of $400 \mathrm{mg}$ twice per day are recommended.

No conflict of interest.

\section{PHC-022 PRACTICAL USE OF THERAPEUTIC DRUG MONITORING OF TEICOPLANIN}

doi:10.1136/ejhpharm-2013-000276.367

R Gomez Marín, J Ruiz Ramírez. Hospital USP San Jaime, Pharmacy Service, Torrevieja, Spain

Background The trough concentration of teicoplanin should be $>10 \mathrm{mg} / \mathrm{L}$ for successful treatment, although it needs to be $>20$ $\mathrm{mg} / \mathrm{L}$ for more severe staphylococcal infections, such as endocarditis and osteomyelitis.

Purpose To analyse the trough serum concentrations for teicoplanin by therapeutic drug monitoring (TDM) in current clinical practise in our hospital.

Materials and Methods Descriptive, analytical, observational study involving the first determination of trough serum concentration of teicoplanin, intravenously administered, from 2010 to 2012. Results Trough serum concentrations of teicoplanin from 48 inpatients (56.3\% female) were analysed. The mean age was 59.8 years (CI95\%: 55.7-63.9). 58.3\% of the inpatients received one single loading dose of $800 \mathrm{mg}$, the other $37.5 \%$ received $400 \mathrm{mg}$ twice daily for the first day, one patient (2.1\%) $400 \mathrm{mg}$ twice daily for two days and another patient (2.1\%) $400 \mathrm{mg}$ each day. $70.8 \%$ of inpatients continued with $400 \mathrm{mg}$ twice daily, 25\% with $400 \mathrm{mg}$ once daily and the rest with $200 \mathrm{mg}$ once daily. The mean dose was $6.9 \mathrm{mg} / \mathrm{kg} /$ day (C195\%: $5.4-8.5 \mathrm{mg} / \mathrm{kg} /$ day). The number of doses received until the first determination was 4.7 (CI95\%: 4.1-5.3 doses)

It was observed that the $37.5 \%$ of inpatients had a trough serum concentration of teicoplanin lower than $10 \mathrm{mg} / \mathrm{L}, 58.3 \%$ between $10-25 \mathrm{mg} / \mathrm{L}$ and $4.2 \%$ greater than $25 \mathrm{mg} / \mathrm{L}$. $64.3 \%$ of the patients received $400 \mathrm{mg}$ once daily and $26.5 \%$ had doses of $400 \mathrm{mg}$ twice daily and had concentrations lower than $10 \mathrm{mg} / \mathrm{L}$.

All patients with concentrations lower than $10 \mathrm{mg} / \mathrm{L}$ were readjusted in their dose and frequency to reach serum trough concentrations greater than $10 \mathrm{mg} / \mathrm{L}$, in steady-state.

Conclusions We found out one problem in our setting. The current TDM of teicoplanin can help to solve it, diminishing the risk of treatment failure or micobiological resistance to teicoplanin.

No conflict of interest.

\section{PHC-023 RATIONAL USE OF MEDICINE IN SWEDISH COMMITTEE FOR AFGHANISTAN HEALTH FACILITIES}

doi:10.1136/ejhpharm-2013-000276.368

'NOOR Noorullah, ${ }^{2} \mathrm{D}$ Ziaullah. 'Swedish Committee for Afghanistan, Health, Kabul, Afghanistan; ${ }^{2} \mathrm{OCHA}$, ICT, Kabul, Afghanistan

Background Medicine and medical commodities constitute essential and important inputs to health service delivery in all health systems. Irrational use of medicines is a multi-dimensional issue and requires interventions at several levels including Health Systems, Organization, Doctors, Dispensers, Patients and Community and it still remains a challenge in health facilities (HF) all over the country, including those managed by the Swedish Committee for Afghanistan (SCA).

Purpose To identify the factors that influence prescribers' behaviour and decision-making (Personal, Interpersonal, Workplace and Informational) while managing medicines and medical supplies.

To provide detailed information for improving the Rational Use of Medicine in SCA health facilities.

Materials and Methods Along with my teams I assessed 4 SCA projects through register books, stock cards, prescriptions, structured questioners and medical records. 28 were selected randomly from $123 \mathrm{HFs}$ with a sampling interval of 5 (every 4th HF). This constituted 10 Comprehensive Health Centres, 9 Basic Health Centres, 5 Sub Centres, 2 District Hospitals and 2 Provincial Hospitals. Results The average number of medicines per encounter was 2.1, ranging between 1.76 in Saripul and 2.49 in Wardak.

Prescription of antibiotics in health facilities visited averaged at $53.4 \%$. It ranged from 48\%.in Saripul and 60\% in Samangan. In Wardak it was $56 \%$ and it was $49 \%$ in Laghman.

The average percentage of injectables prescribed was 7.8 percent. Laghman prescribed $10 \%$, Saripul $6.22 \%$, Samangan $8 \%$ and Wardak $7 \%$.

Conclusions Irrational use of medicines is a complex issue and calls for multi-dimensional interventions.

RUM training for professional staff and health education and awareness programmes for people who are living in rural areas as well as distribution of standard treatment guidelines will play a significant role in promoting the rational use of medicine.

\section{Abstract PHC-023 Table 1}

\begin{tabular}{llllll}
\hline Indicator & Wardak & Laghman & Samangan & Saripul & $\begin{array}{l}\text { Total } \\
\text { Average }\end{array}$ \\
\hline $\begin{array}{l}\text { Average number of medicines } \\
\text { prescribed per encounter }\end{array}$ & 2.49 & 1.94 & 2.24 & 1.76 & $\mathbf{2 . 1 1}$ \\
$\begin{array}{l}\text { Percentage of antibiotics } \\
\text { prescribed per encounter }\end{array}$ & $56 \%$ & $49 \%$ & $60 \%$ & $48 \%$ & $\mathbf{5 3 . 4 \%}$ \\
$\begin{array}{l}\text { Percentage of injectable } \\
\text { prescribed per encounter }\end{array}$ & $7 \%$ & $10 \%$ & $8 \%$ & $6.22 \%$ & $\mathbf{7 . 8} \%$ \\
\hline
\end{tabular}

No conflict of interest.

\section{PHC-024 RENAL FUNCTION ESTIMATION BY DIFFERENT METHODS (CKD-EPI,COCKCROFT-GAULT AND MDRD4-IDMS) AND ITS EFFECT ON THE DOSE OF IV DEXKETOPROFEN}

doi:10.1136/ejhpharm-2013-000276.369

M de Dios Garcia, C Salazar Valdebenito, M Alcalde Rodrigo, M Munné Garcia, I Cardona Pascual, JB Montoro Ronsano. Hospital Universitari Vall d'Hebron, Pharmacy, Barcelona, Spain

Background The different methods that currently exist to estimate renal function take into account different parameters, which may affect the dose of some drugs, such as dexketoprofen.

The recommended dose of IV dexketoprofen is $50 \mathrm{mg}$ every 8 hours if eGFR is $>80 \mathrm{~mL} / \mathrm{min} / 1.73 \mathrm{~m}^{2}, 25 \mathrm{mg}$ every 12 hours if eGFR is between $50-80 \mathrm{~mL} / \mathrm{min} / 1.73 \mathrm{~m}^{2}$ and it is contraindicated if eGFR is $<50 \mathrm{~mL} / \mathrm{min} / 1.73 \mathrm{~m}^{2}$ - according to the summary of product characteristics.

Purpose To determine the differences in the estimates of renal function, using CKD-EPI, MDRD4-IDMS and Cockcroft-Gault (CG) to estimate the glomerular filtration rate (eGFR) and to assess their effect on the functional characterization of patients and the dose of IV dexketoprofen.

Materials and Methods Retrospective observational study performed in adults admitted to surgical units - general, trauma and obstetric - treated with dexketoprofen IV in a tertiary hospital from January to September 2011 (9 months). 
The eGFR was calculated by CKD-EPI, MDRD4-IDMS and Cockcroft-Gault. Patients with serum creatinine below $0.4 \mathrm{mg} / \mathrm{dl}$ were excluded.

CKD-EPI was used as a reference formula to assess the concordance between the different methods of estimating, classifying patients in 3 eGFR groups according to the IV dexketoprofen SmPC: $<50 \mathrm{~mL} / \mathrm{min} / 1.73 \mathrm{~m}^{2}, 50-80 \mathrm{~mL} / \mathrm{min} / 1.73 \mathrm{~m}^{2}$ and $>80 \mathrm{~mL} / \mathrm{min} /$ $1.73 \mathrm{~m}^{2}$.

Results The study included 1946 patients - 54.3\% men, 45.7\% women - from a total population of 2052 admissions; mean age of 59.8 years (range $17-103$ ). The mean serum creatinine concentration was $0.84 \mathrm{mg} / \mathrm{dL} \pm 0.43$ and mean eGFR, according to CKDEPI, $83.05 \pm 26.17 \mathrm{~mL} / \mathrm{min} / 1.73 \mathrm{~m}^{2}$.

The following results of non-concordance were found by comparing these formulas to estimate renal function:

- CKD-EPI vs. MDRD4-IDMS: $4.3 \%$ in eGFR $<50 \mathrm{~mL} /$ $\mathrm{min} / 1.73 \mathrm{~m}^{2}$ group, $23.2 \%$ in the eGFR $50-80 \mathrm{~mL} / \mathrm{min} / 1.73$ $\mathrm{m}^{2}$ and $18.9 \%$ in eGFR $>80 \mathrm{~mL} / \mathrm{min} / 1.73 \mathrm{~m}^{2}$.

- CKD-EPI vs. CG: $2.8 \%$ in eGFR $<50 \mathrm{~mL} / \mathrm{min} / 1.73 \mathrm{~m}^{2}$ group, $10.5 \%$ in eGFR $50-80 \mathrm{~mL} / \mathrm{min} / 1.73 \mathrm{~m}^{2}$ and $7.8 \%$ in eGFR $>$ $80 \mathrm{~mL} / \mathrm{min} / 1.73 \mathrm{~m}^{2}$.

- MDRD4-IDMS vs. CG: $4.5 \%$ in the group of eGFR $<50 \mathrm{ml} /$ min, $21.4 \%$ in group eGFR $50-80 \mathrm{~mL} / \mathrm{min}$ and $17.1 \%$ in the group of eGFR $>80 \mathrm{ml} / \mathrm{min}$.

Conclusions A great difference was found in the estimates of renal function between the three methods used - CKD-EPI, MDRD4IDMS and CG - in the three eGFR functional categories $-<50$, $50-80$ and $>80 \mathrm{~mL} / \mathrm{min} / 1.73 \mathrm{~m}^{2}$ - ranging between $2.8 \%$ and $23.2 \%$.

These results are relevant in clinical practise because the functional category determines the non-use or limited dose of dexketoprofen IV for each patient.

No conflict of interest.

\section{PHC-025 SINGLE NUCLEOTIDE POLYMORPHISMS ASSOCIATED WITH ADVERSE EVENTS IN TAXANE-TREATED BREAST CANCER PATIENTS}

doi:10.1136/ejhpharm-2013-000276.370

${ }^{1} \mathrm{~V}$ Bosó-Ribelles, ${ }^{1} \mathrm{MJ}$ Herrero-Cervera, ${ }^{2} \mathrm{~A}$ Santaballa-Beltran, ${ }^{2} \mathrm{~L}$ Palomar-Abad, ${ }^{2} \mathrm{H}$ de la Cueva-Sapiña, ${ }^{2} \mathrm{~J}$ Montalar-Salcedo, ${ }^{3}$ SF Aliño-Pellicer, ${ }^{1} \mathrm{JL}$ Poveda-Andrés. ${ }^{1}$ Hospital Universitario La Fe, Pharmacy, Valencia, Spain; ${ }^{2}$ Hospital Universitario La Fe, Medical Oncology, Valencia, Spain; 'Universidad de Valencia, Pharmacology Department. Facultad de Medicina, Valencia, Spain

Background Inter-individual differences in drug efficacy and toxicity are linked, in many cases, to single nucleotide polymorphisms (SNPs) in genes coding for drug metabolising enzymes and transporters. Taxanes are active for several tumour types, including breast cancer. But this is limited by adverse events such as neurotoxicity and haematological toxicity.

Purpose To evaluate the associations between a panel of 92 SNPs in 33 genes and adverse events developed by breast cancer patients treated with taxanes.

Materials and Methods Between June 2011 and May 2012 breast cancer patients treated with taxanes who gave informed consent were genotyped for 92 SNPs in 33 genes. Genomic DNA was analysed by a genetic analysis platform (MassArray, Sequenom). HardyWeinberg equilibrium was assessed. Clinical data were recorded. The association between genotypes and adverse reactions was assessed with Fisher's exact test and X2-test.

Results Sixty-seven Caucasian women (mean age: 53 years old; $95 \% \mathrm{CI}=49-56$ ) were genotyped. All genotype frequencies were in Hardy-Weinberg equilibrium. $53.7 \%(n=36)$ of the patients were treated with docetaxel and $46.3 \%(n=31)$ with paclitaxel. Histotypes: $88.1 \%(n=59)$ ductal, $7.5 \%(n=5)$ lobular and $4.5 \%(n=3)$ other. Significant associations were found between: A) Overall grade III-IV toxicity: TP53 rs 1045522 [10.8\% $(\mathrm{n}=4) \mathrm{GG}$ vs. $43.3 \%$ $(\mathrm{n}=13) \mathrm{GC} / \mathrm{CC}, \mathrm{p}=0.004]$; DNA repair gene XPC rs2228001 [8.7\% $(\mathrm{n}=2)$ AA vs. $34.1 \%(\mathrm{n}=15)$ AC/CC, $\mathrm{p}=0.037] . \mathrm{B})$ Anaemia grade II-IV: ERCC2 rs 1799793 [7.1\% $(\mathrm{n}=2)$ GG vs. 33.3\% $(\mathrm{n}=13)$ GA/AA, $p=0.016] ;$ XPC rs 2228001 [4.3\% $(n=1)$ AA vs. 31.8\% ( $n=$ 14) $\mathrm{AC} / \mathrm{CC}, \mathrm{p}=0.012]$. C) Neutropenia grade II-IV: CYP2C8 rs1341164 [6.5\% ( $\mathrm{n}=2)$ TT vs. $27.8 \%(\mathrm{n}=10)$ TC/CC, $\mathrm{p}=0.028]$; TP53 rs 1045522 [8.1\% (n=3) GG vs. $30.0 \%(\mathrm{n}=9) \mathrm{GC} / \mathrm{CC}$, $\mathrm{p}=0.027$ ] XPC rs2228001 [0.0\% AA vs. $27.3 \%(\mathrm{n}=12) \mathrm{AC} / \mathrm{CC}$, $\mathrm{p}=0.006]$. D) Diarrhoea grade II-IV: $A B C B 1$ rs1128503 [21.4\% $(\mathrm{n}=6)$ TT vs. $2.6 \%(\mathrm{n}=1) \mathrm{TC} / \mathrm{CC}, \mathrm{p}=0.018]$; CYP1B1 rs72549389 $[20.0 \%(n=7)$ TT vs. $0 \%$ TG/GG, $p=0.014]$. No associations with neurotoxicity were found.

Conclusions Studying genetic variations can help to identify patients at higher risk of suffering adverse events and provides useful information to individualise therapy.

No conflict of interest.

\section{PHC-026 TACROLIMUS AND IMATINIB INTERACTION. A CASE STUDY}

doi:10.1136/ejhpharm-2013-000276.371

P Selvi-Sabater, AM Rizo-Cerda, B Arribas-Diaz, A Morego-Soler, A Bosó-Ribelles, 'MC Sánchez-Mulero, I Sánchez-Martinez, N Manresa-Ramón, A Espuny Miro, C CastillaLlorente. Hospital Morales Meseguer, Pharmacy, Murcia, Spain

Background Tacrolimus is a drug metabolised by CYP3A4. Since imatinib increases the plasma concentrations of simvastatin, a CYP3A4 substrate, this indicates that it is an inhibitor of this enzyme and may affect other drugs.

Purpose To describe the possible interaction between imatinib and tacrolimus that result in increased blood levels of Tacrolimus.

Materials and Methods Information was collected through the SAVAC and SELENE computer systems and reviewing patient history. The variables compiled were tacrolimus blood levels, dose and dose regimen.

Results The patient had an allogeneic blood stem cells transplant from an unrelated donor, HLA and $\mathrm{ABO}$ compatible, presenting cutaneous sclerodermiform graft versus host disease (GVHD) on tacrolimus $(2 \mathrm{mg} / 12 \mathrm{~h}$ ) treatment and blood levels around $4 \mathrm{ng} / \mathrm{ml}$ for 12 weeks. After starting treatment with imatinib, in the following five tests tacrolimus levels ranged from $5.8 \mathrm{ng} / \mathrm{ml}$ to $8.9 \mathrm{ng} / \mathrm{ml}$ with no change in the dose of tacrolimus. After 45 days of treatment imatinib was suspended and tacrolimus levels recorded in the following test after discontinuation of imatinib fell to around $4 \mathrm{ng} / \mathrm{ml}$. Conclusions The increase in tacrolimus blood levels, without changing the dose, supports the possible interaction between imatinib and tacrolimus.

No conflict of interest.

\section{PHC-027 THE PHARMACIST'S ROLE IN IMPROVING VALPROIC ACID PRESCRIPTIONS}

doi:10.1136/ejhpharm-2013-000276.372

B San José, Z Baskaran, I Bilbao, A De Basagoiti, A Belaustegi, J Hernández, S Sautua M Castaño, A Bustinza, MA Gil. Hospital de Cruces, Servicio de Farmacia, Barakaldo, Spain

Background Valproic acid (VPA) is $90-95 \%$ protein bound to albumin; this binding can be saturated so other parameters that can modify the free fraction of VPA should be taken into account.

Purpose To identify areas for improvement in VPA use and monitoring in a tertiary hospital where the pharmacy service does not routinely send pharmacokinetic dose adjustment recommendations. 